\title{
PEMANFAATAN VIDEO SCRIBE UNTUK MENINGKATKAN HASIL BELAJAR MATERI CITA-CITAKU MENJADI ANAK SHALIH DI SEKOLAH DASAR
}

\author{
Zubaidah \\ SD Negeri 25 Sungai Kakap \\ Email:zubaidahsd25kakap@gmail.com
}

\begin{abstract}
Abstrak
Penelitian ini adalah penelitian tindakan kelas yang bertujuan untuk mengetahui apakah pemanfaatan Video Scribe dapat meningkatkan hasil belajar siswa padapelajaran Pendidikan Agama Islam materi cita-citaku menjadi anak shalih di kelas V SD Negeri 25 Sungai Kakap. Video scribe adalah media penyampai materi berbentuk audio visual menarik dan di setting sesuai usia anak SD agar siswa termotivasi mengikuti proses pembelajaran. Penelitian tindakan kelas ini dilaksanakan dua siklus, setiap siklus terdiri dari empat tahapan utama, yaitu: perencanaan, pelaksanaan kegiatan, pengamatan (observasi) dan refleksi. Setiap akhir kegiatan dilakukan refleksi, sehingga kelemahan-kelemahan setiap siklus dapat dibenahi pada siklus berikutnya. Berdasarkan hasil penelitian menunjukkan bahwa terjadi peningkatan hasil belajar siswa setelah memanfaatkan media video scribe yaitu pada pra penelitian sebanyak 5 atau $25 \%$ siswa mencapai KKM, kemudian pada siklus I terjadi peningkatan 12 atau $60 \%$ siswa mencapai KKM, dan pada siklus II menunjukkan terjadi peningkatan yaitu 20 atau 100\% siswa telah mencapai KKM.
\end{abstract}

\section{Kata Kunci: Video Scribe, Hasil Belajar, SD}

\section{PENDAHULUAN}

Meningkatkan kualitas sumber daya manusia merupakan salah satu hal penting yang harus diperhatikan. Salah satu langkah mewujudkannya adalah melalui pendidikan. Pendidikan tersebut merupakan langkah dalam membentuk manusia seutuhnya, menjadikannya menjadi lebih baik secara sadar tanpa keterpaksaan.

Komponen penting untuk meningkat mutu pendidikan adalah pendidik. Karena pendidik merupakan ujung tombak keberhasilan generasi bangsa. Namun dalam proses pelaksanaan pembelajaran dalam meningkatkan pendidikan, banyak kendala atau masalah-masalah yang dihadapi guru. Salah satu kendala tersebut adalah minat dan motivasi siswa dalam mengikuti proses yang dilaksanakan dan pada akhirnya berpengaruh pada hasil belajar siswa yang tidak mencapai standar ketuntasan yang ditetapkan (KKM).

Berdasarkan hal tersebut diatas, penulis memperhatikan bahwa perkembangan teknologi di era globalissi yang semakin pesat. Hal ini mampu atau dapat membantu guru dalam melakukan inovasi dalam pembelajaran yang dilaksanakan sehingga proses yang dilaksanakan menarik, menyenangkan dan mempermudah siswa memahami materi yang disampaikan.

Kemajuan teknologi ini sangat berhubungan dengan cara hidup manusia. Pendidikan sebagai tempat mewujudkan manusia berkualitas, menuntut para pendidik untuk mampu memanfaatkan alat-alat yang mampu mendukung proses belajar mengajar disekolah seperti alat-alat audio, visual, grafis, chart maupun pembelajaran berbasis video. untuk siswa Muslim pada sekolah umum sebagai Penelitian Tindakan Kelas ini peneliti dilaksanakan di SD Negeri 25 Sungai Kakap dikarenakan rendahnya hasil belajar, pembelajaran yang dilaksanakan masih bersifat konvensional dan kurang maksimalnya penggunaan media dalam kegiatan belajar mengajar. Hal ini menjadikan siswa pasif dan belum mencapai Ketuntasan Minimal (KKM). Peneliti kemudian memanfaatkan video scribe agar siswa mudah memahami dan mengingat materi yang dipelajari sehingga mampu meningkat dan mempengaruhi hasil belajar siswa menjadi lebih memuaskan dan mencapai Kriteria Ketuntasan Minimal (KKM).

Penelitian ini fokus pada materi cita-citaku menjadi anak shalih di kelas V Sekolah Dasar. Pemilihan materi dikarenakan masih rendahnya nilai siswa yang belum mencaai KKM yang ditetapkan. Pemilihan kelas dianggap sangat tepat untuk menerapkan penggunaan media video scribe. Penggunaan media ini membuat pelajaran mengenai konsep ataupun klasifikasi 
materi menjadi mudah untuk dipahami.

Berdasarkan uraian diatas, maka peneliti melakukan penelitian tindakan kelas dengan judul: "Pemanfaatan Video Scribe Untuk Meningkatkan Hasil Belajar Pendidikan Agama Islam Kelas V SD Negeri 25 Sungai Kakap". Adapun rumusan masalah penelitian ini adalah apakah pemanfaatan video Scribe dapat meningkatkan hasil belajar siswa pada Pendidikan Agama Islam materi cita-citaku menjadi anak shalih di kelas V SD Negeri 25 Sungai Kakap?.

Media adalah perantara atau pengantar pesan dari pengirim pesan ke penerima pesan (Arief Sadiman,2010: 6) Pembawa pesan dapat berupa orang atau benda. Dalam proses pembelajaran penerima pesan adalah peserta didik. Dengan media diharapkan agar pesan yang disampaikan oleh pengajar atau pembel ajaran dapat diserap oleh peserta didik dengan sebanyak-banyaknya. Media yang digunakan pada penelitian ini adalah Video Scribe yang dibuat dan dimanfaatkan oleh pendidik dalam pembelajaran.

\section{METODE PENELITIAN}

Metode penelitian yang digunakan dalam menyusun penelitian tindakan kelas ini adalah penelitian lapangan yang dilakukan di SD Negeri 25 Sungai Kakap. Rancangan penelitian ini menggunakan Penelitian Tindakan Kelas (PTK). Penelitian tindakan kelas merupakan langkah memperbaiki mutu pembelajaran dan meningkatkan profesionalisme pendidik, karena pendidik adalah orang yang mengalami segala masalah dilapangan sehingga mereka mengetahui seluk beluk kelemahan dan kelebihan dalam pembelajaran yang dilaksanakan (Daryono, 2018: 1).

Penelitian tindakan kelas (PTK) ini mengambil bentuk penelitian kerjasama antara peneliti yaitu guru mata pelajaran Pendidikan Agama Islam beserta teman sejawat yang mengajar di SD Negeri 25 Sungai Kakap. Dilakukan di kelas $\mathrm{V}$ dengan jumlah siswa sebanyak 20 orang. Pengumpulan data pada penelitian ini dilakukan dengan: (1) Observasi; (2) Dokumenyasi; (3) Tes hasil belajar atau achievement tes. Instrumen penelitian terdiri dari: (1) lembar observasi, sebagai alat yang digunakam dalam mengobservasi penelitian ini berisikan indikator yang didesain berdasarkan fokus penelitian. Observasi dilakukan untuk mengamati guru dalam menerapkan media video scribe; (2) Pedoman dokumentasi sebagai teknik pengumpulan data yang dapat membantu peneliti dalam mengumpulkan data penelitian yang berupa foto kegiatan proses pembelajaran dengan menggunakan media video; (3) Tes, untuk mengetahui evaluasi hasil pemahaman siswa.

Dalam analisis lanjut ini peneliti mengevaluasi hasil atau kesimpulan yang didapat pada analisis data pada siklus yang sudah terlaksana dan setelah melakukan refleksi mengenai hasil ketuntasan siswa yang diperoleh dari tiap-tiap siklus. Maka hasil dari evaluasi tersebut digunakan untuk membuat rencana analisis lanjutan (Sudjana, 2006: 34). Dengan analisis data tersebut peneliti dapat mengetahui seberapa besar peningkatan hasil belajar siswa terhadap materi Cita-Citaku Menjadi Anak Shalih dengan menggunakan media video scribe

\section{HASIL DAN PEMBAHASAN PENELITIAN}

Keadaaan awal pada pembelajaran Pendidikan Agama Islam di Kelas V SD Negeri 25 Sungai Kakap menunjukkan hasil belajar siswa belum mencapai KKM. Proses pembelajaran yang dilaksanakan oleh guru masih bersifat konvensional, guru mengajar masih menggunakan metode ceramah. Hal ini mengakibatkan peserta didik tidak konsentrasi dalam proses pembelajaran, mereka ribut dan berbicara sendiri. Berdasarkan pengamatan terhadap siswa sebelum melakukan penelitian, menunjukkan bahwa kemampuan siswa masih rendah terhadap mata pelajaran PAI terutama pada materi cita-citaku menjadi anak salih. Hasil belajar siswa dalam mata pelajaran PAI dapat dilihat pada tabel data frekuensi berikut:

Tabel 1. Data Nilai Hasil Belajar Pra Tindakan

\begin{tabular}{cccc}
\hline No & Nama Siswa & Nilai & Keterangan KKM $=\mathbf{7 5}$ \\
\hline 1 & ACC & 64 & Belum Tuntas \\
\hline 2 & BKL & 65 & Belum Tuntas \\
\hline 3 & CKL & 67 & Belum Tuntas \\
\hline 4 & DFG & 70 & Belum Tuntas \\
\hline 5 & EFT & 79 & Tuntas \\
\hline
\end{tabular}




\begin{tabular}{cccc}
\hline 6 & FFO & 59 & Belum Tuntas \\
\hline 7 & GJH & 70 & Belum Tuntas \\
\hline 8 & HJD & 80 & Tuntas \\
\hline 9 & IDS & 80 & Tuntas \\
\hline 10 & JFT & 70 & Belum Tuntas \\
\hline 11 & KID & 60 & Belum Tuntas \\
\hline 12 & LYA & 64 & Belum Tuntas \\
\hline 13 & MKH & 70 & Belum Tuntas \\
\hline 14 & NJG & 69 & Belum Tuntas \\
\hline 15 & ODN & 66 & Tuntas \\
\hline 16 & PXC & 80 & Belum Tuntas \\
\hline 17 & QOG & 68 & Tuntas \\
\hline 18 & RYI & 80 & Belum Tuntas \\
\hline 19 & SUT & 66 & Belum Tuntas \\
\hline 20 & TDE & 60 & \\
\hline \multicolumn{7}{r}{} & Jumlah & 69.387 & (5 Siswa) \\
\hline & Pata-Rata & & (15 Siswa) \\
\hline
\end{tabular}

Melalui tabel di atas dapat diketahui bahwa jumlah siswa yang telah tuntas sebanyak 5 siswa (25\%), sedangkan siswa yang belum tuntas sebanyak 15 siswa (75\%). Hal ini membuktikan rendahnya nilai ketuntasan prestasi belajar yang tidak sesuai dengan kriteria ketuntasan minimal (KKM) yang diharapkan. Data di atas menjadi dasar dalam menerapkan pembelajaran dengan menggunakan media video scribe pada siswa kelas V SD Negeri 25 Sungai Kakap.

Pelaksanaan siklus I ini dilakukan dengan serangkaian kegiatan berupa pemberian tes awal dan tes akhir sesuai dengan jadwal yang sudah ditentukan. Beberapa kegiatan yang dilaksanakan oleh peneliti, sebelum melakukan tindakan penelitian, terlebih dahulu pada awal penelitian melakukan pra tindakan yaitu berdiskusi secara kolaborasi dengan teman sejawat proses pembelajaran PAI dengan memanfaatkan media video scribe dalam proses pembelajaran. Sebelum melakukan tindakan peneliti melakukan tes awal yang bertujuan untuk mengukur pengetahuan awal siswa kelas V SD Negeri 25 Sungai Kakap tentang materi cita-citaku menjadi anak shalih.

Tahap perencanaan ini mengenai persiapan segala sesuatu yang berkaitan dengan kegiatan peneliti yang terdiri dari: (1) Membicarakan rencana penelitian tindakan kelas antara peneliti dengan teman sejawat; (2) Melakukan penyusunan kegiatan yang akan dilakukan; (3) Mempersiapkan RPP (Rencana Pelaksanaan Kegiatan) yang memuat seluruh konsep kegiatan pembelajaran sesuai dengan pokok bahasan; (4) Menyiapkan alat dan media pembelajaran (LCD dan Proyektor); (5) Membuat Instrumen Penilaian, meliputi : Lembar observasi kegiatan siswa untuk mengamati proses pembelajar dan kemampuan siswa, dab lembar observasi kegiatan guru untuk mengumpulkan data tentang ketetapan guru dalam menggunakan media video scribe

Tahap pelaksanaan siklus I dilaksanakan hari Rabu 6 September 2018 dengan menggunakan bahan pembelajaran: (1) materi cita-citaku menjadi anak shalih; (2) Siswa yang hadir: 20 siswa (100\%); (3) Alat dan sumber pembelajaran: rangkuman materi cita-citaku menjadi anak salih dan LKS serta menggunakan media video scribe; (4) Kegiatan pokok pembelajaran yaitu; (a) Mengamati video scribe yang ditayangkan dan mencermati materi atau pesan yang terkandung pada video tersebut; (a) Menanya; (c) menalar; (d) mengasosiasi. 


\begin{tabular}{|c|c|c|c|c|c|c|c|c|c|c|}
\hline \multirow[t]{3}{*}{ No } & \multirow[t]{3}{*}{ Nama Siswa } & & & \multicolumn{7}{|c|}{ Aspek Yang Dinilai } \\
\hline & & \multicolumn{3}{|c|}{$\begin{array}{l}\text { Keaktifan } \\
\text { Siswa }\end{array}$} & \multicolumn{3}{|c|}{$\begin{array}{l}\text { Perhatian } \\
\text { Siswa }\end{array}$} & \multicolumn{3}{|c|}{$\begin{array}{c}\text { Penguasan } \\
\text { Materi }\end{array}$} \\
\hline & & 3 & 2 & 1 & 3 & 2 & 1 & 3 & 2 & 1 \\
\hline 1 & ACC & & $\mathrm{V}$ & & & $\mathrm{V}$ & & & $\mathrm{V}$ & \\
\hline 2 & BKL & & & $\mathrm{V}$ & & $\mathrm{V}$ & & & $\mathrm{V}$ & \\
\hline 3 & CKL & & $\mathrm{V}$ & & & $\mathrm{V}$ & & & $\mathrm{V}$ & \\
\hline 4 & $\overline{D F G}$ & & & $\mathrm{~V}$ & & $\mathrm{~V}$ & & & $\mathrm{~V}$ & \\
\hline 5 & EFT & $\mathrm{V}$ & & & & & $\mathrm{V}$ & & $\mathrm{V}$ & \\
\hline 6 & FFO & & $\mathrm{V}$ & & & & $\mathrm{V}$ & & & $\mathrm{V}$ \\
\hline 7 & GJH & & $\mathrm{V}$ & & & & $\mathrm{V}$ & & $\mathrm{V}$ & \\
\hline 8 & HJD & & & $\mathrm{V}$ & & $\mathrm{V}$ & & & & $\mathrm{V}$ \\
\hline 9 & IDS & & $\mathrm{V}$ & & & & $\mathrm{V}$ & & $\mathrm{V}$ & \\
\hline 10 & JFT & & $\mathrm{V}$ & & & $\mathrm{V}$ & & & $\mathrm{V}$ & \\
\hline 11 & KID & & & $\mathrm{V}$ & & & $\mathrm{V}$ & & & $\mathrm{V}$ \\
\hline 12 & LYA & & & $\mathrm{V}$ & & & $\mathrm{V}$ & & & $\mathrm{V}$ \\
\hline 13 & MKH & & $\mathrm{V}$ & & & $\mathrm{V}$ & & & $\mathrm{V}$ & \\
\hline 14 & NJG & $\mathrm{V}$ & & & & & $\mathrm{V}$ & & $\mathrm{V}$ & \\
\hline 15 & ODN & $\mathrm{V}$ & & & $\mathrm{V}$ & & & & & $\mathrm{V}$ \\
\hline 16 & $\mathrm{PXC}$ & & $\mathrm{V}$ & & $\mathrm{V}$ & & & & $\mathrm{V}$ & \\
\hline 17 & QOG & & $\mathrm{V}$ & & $\mathrm{V}$ & & & & $\mathrm{V}$ & \\
\hline 18 & RYI & & $\mathrm{V}$ & & & $\mathrm{V}$ & & & $\mathrm{V}$ & \\
\hline 19 & SUT & & $\mathrm{V}$ & & & $\mathrm{V}$ & & & $\mathrm{V}$ & \\
\hline \multirow[t]{2}{*}{20} & TDE & & & $\mathrm{V}$ & & $\mathrm{V}$ & & & & $\mathrm{V}$ \\
\hline & & 3 & 11 & 6 & 3 & 10 & 9 & - & 14 & 6 \\
\hline
\end{tabular}

Keterangan $=3$ (Tinggi), 2 (Sedang), 1 (Rendah)

Data siklus I diperoleh dengan menggunakan lembar observasi pada siswa. Data di atas menunjukkan bahwa keaktifan siswa pada siklus I ini $15 \%$ tinggi, $55 \%$ sedang dan $30 \%$ rendah. Dari hasil persentase tersebut sudah cukup baik namun masih ada beberapa siswa yang memiliki keaktifan rendah. Hasil untuk aspek perhatian siswa $15 \%$ tinggi, 50\% sedang, $35 \%$ rendah. Dalam bertanya siswa masih takut terhadap guru. Perhatian siswa dalam pelajaran juga belum sepenuhnya tercurahkan pada pembelajaran. Hasil untuk aspek penguasaan materi $0 \%$ tinggi, $70 \%$ sedang dan $30 \%$ rendah. Masih banyak siswa yang tidak menguasai materi secara menyeluruh dan ada beberapa yang belum dapat menguasai materi. Pada siklus I ini jumlah siswa yang telah tuntas sebanyak 12 siswa (60\%), sedangkan siswa yang belum tuntas sebanyak 8 siswa (40\%). Sehingga dilakukan penelitian tindakan kelas selanjutnya.

Pada siklus II diperoleh dengan menggunakan lembar observasi pada siswa, soal uraian dan lembar penilaian tugas proyek. Berikut adalah tabel pengamatan pada siswa.

Tabel 3. Hasil Pengamatan Terhadap Siswa Siklus II

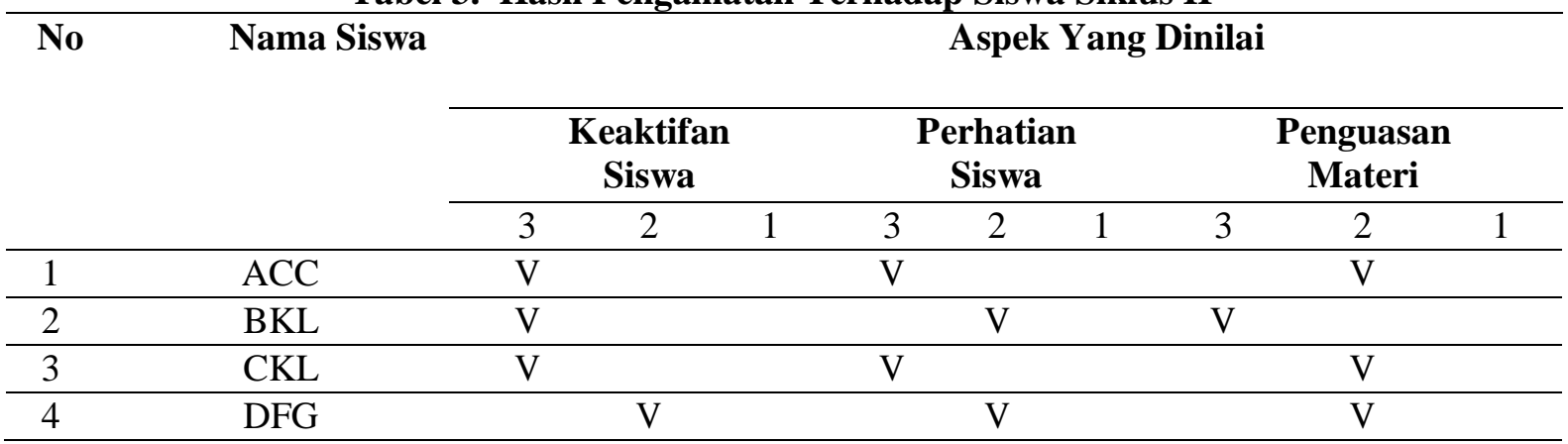




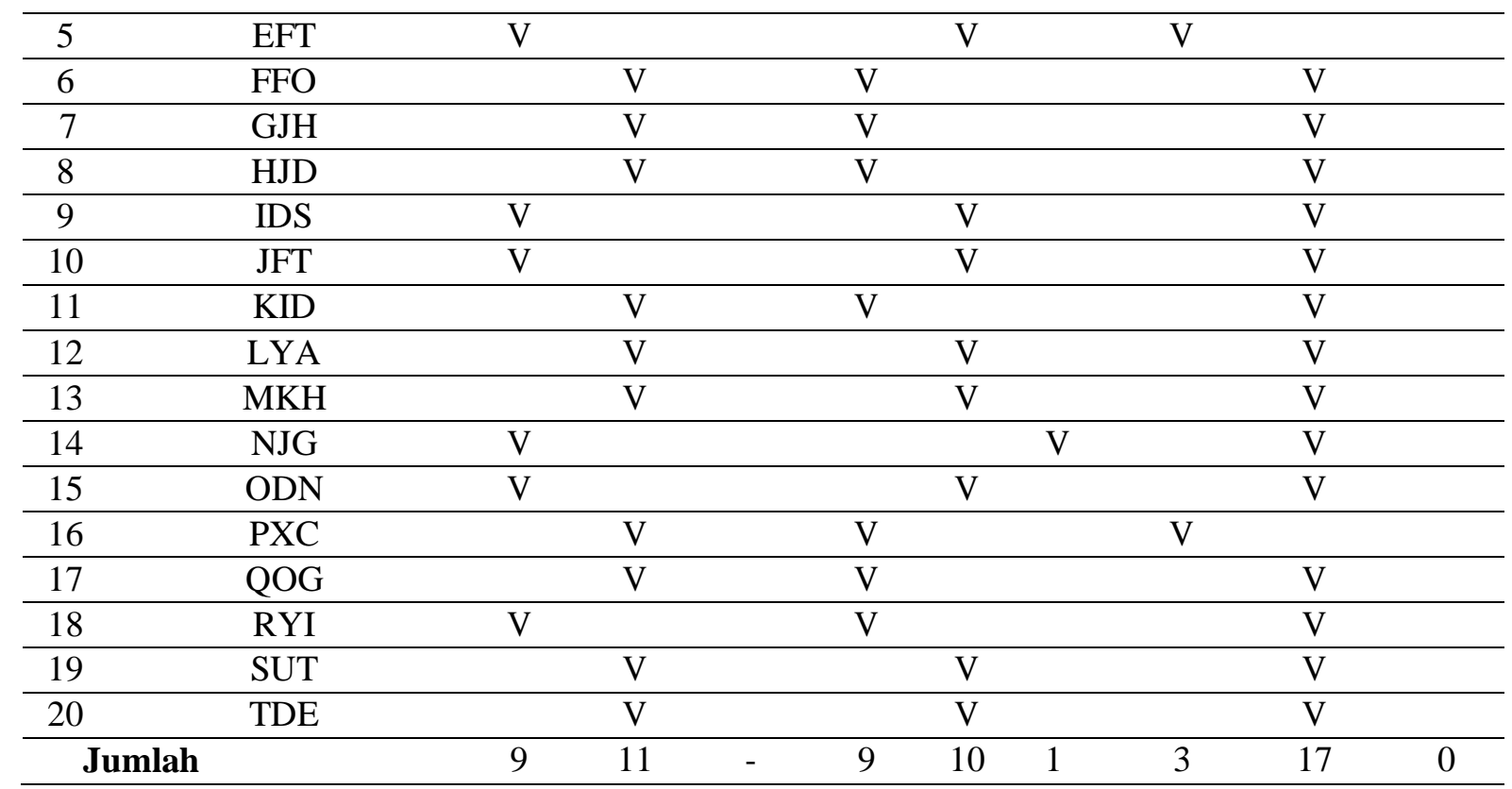

Keterangan $=3$ (Tinggi), 2

Pada siklus II ini menunjukkan bahwa keaktifan, perhatian dan penguasaan siswa pada siklus II ini mengalami peningkatan. Data di atas menunjukkan bahwa keaktifan siswa pada siklus II ini 55\% tinggi, 55\% sedang dan 0\% rendah. Dari hasil persentasi menunjukkan adanya kemajuan jika dibandingkan dengan siklus sebelumnya. Dan hasil untuk aspek perhatian siswa $45 \%$ tinggi, 50\% sedang, 5\% rendah. Dalam bertanya siswa mulai dapat berani
(Sedang), 1

memberi masukan atau ide-ide terhadap masalahmasalah yang diberikan guru. Siswa sudah semakin focus pada proses pembelajaran yang dilaksanakan. Serta hasil untuk aspek penguasaan materi $15 \%$ tinggi, $85 \%$ sedang dan $0 \%$ rendah. Sebagian besar siswa telah memamahami materi secara menyeluruh dan masih ada sebagian kecil yang belum memamhami materi yang disajikan. Sedangkan hasil belajar siswa dengan menggunakan tes formatif diperoleh data sebagai berikut

Tabel 4. Data Hasil Belajar Siswa pada Siklus II

\begin{tabular}{cccc}
\hline No & Nama Siswa & Nilai & Keterangan \\
\hline 1 & ACC & 86 & Tuntas \\
\hline 2 & BKL & 90 & Tuntas \\
\hline 3 & CKL & 88 & Tuntas \\
\hline 4 & DFG & 90 & Tuntas \\
\hline 5 & EFT & 86 & Tuntas \\
\hline 6 & FFO & 84 & Tuntas \\
\hline 7 & GJH & 80 & Tuntas \\
\hline 8 & HJD & 76 & Tuntas \\
\hline 9 & IDS & 88 & Tuntas \\
\hline 10 & JFT & 80 & Tuntas \\
\hline 11 & KID & 78 & Tuntas \\
\hline 12 & LYA & 80 & Tuntas \\
\hline 13 & MKH & 84 & Tuntas \\
\hline 14 & NJG & 86 & Tuntas \\
\hline 15 & ODN & 78 & Tuntas \\
\hline 16 & PXC & 82 & Tuntas \\
\hline 17 & QOG & 80 & \\
\hline
\end{tabular}




\begin{tabular}{llll}
\hline 18 & RYI & 92 & Tuntas \\
\hline 19 & SUT & 86 & Tuntas \\
\hline 20 & TDE & 78 & Tuntas \\
\hline
\end{tabular}

Hasil data yang diperoleh dari tabel di atas dapat dilihat bahwa pada siklus II, jumlah seluruh siswa yang mencapai nilai KKM sebanyak 20 siswa atau $100 \%$. Sehinggga dengan memanfaatkan media video scribe ini dapat meningkatkan motivasi, semangat dala mengikuti proses pembelajaran yang pada akhirnya berpengaruh pada hasil belajar yang semakin memuaskan atau mencapai target yang telah ditetapkan sekolah.
Setelah melakukan penelitian kegiatan pada siklus I dan siklus II diperoleh data nilai PAI dengan menggunakan media video scribe pada siswa kelas V SD Negeri 25 Sungai Kakap. Berikut hasil penelitian siklus I dan siklus II. Hasil pengamatan siklus I diperoleh data nilai prestasi belajar, sehingga dapat dibandingkan dengan nilai prestasi belajar pra tindakan dalam bentuk frekuensi. Kemudian disimpulkan dalam bentuk tabel di bawah ini:

Tabel 5. Rekapitulasi Pra Tindakan dengan Siklus I

\begin{tabular}{cccc}
\hline No & Keterangan (KKM=75) & Pra Tindakan & Siklus I \\
\hline 1. & Persentase Ketuntasan & $25 \%$ & $60 \%$ \\
\hline 2. & Tuntas & 5 siswa & 12 siswa \\
\hline 3. & Belum Tuntas & 15 siswa & 8 siswa \\
\hline & Jumlah & 20 siswa & 20 siswa \\
\hline
\end{tabular}

Dari tabel di atas, dapat dilihat terjadi peningkatan ketuntasan belajar siswa dari 5 siswa atau 25\% menjadi 12 siswa atau $60 \%$. Pada siklus I ini hasil belajar siswa mengalami peningkatan dari kondisi awal sebelum penelitian atau pra penelitian. Artinya pada siklus I telah mengalami peningkatan hasil belajar sebesar $35 \%$. Dan masih ada beberapa siswa yang belum tuntas yang diharapkan pada siklus berikutnya akan mendapat perbaikan.

Hasil dari aspek keaktifan siswa siklus I sebesar persentase tinggi 15\%, sedang 55\%, rendah $30 \%$ dan pada siklus II dalam aspek keaktifan siswa mengalami peningkatan menjadi persentase tinggi $45 \%$, sedang $55 \%$ dan rendah $0 \%$. Hasil persentase dalam aspek perhatian siswa pada siklus I adalah tinggi $15 \%$,sedang $50 \%$ dan rendah $35 \%$, pada siklus II mengalami peningkatan menjadi tinggi $45 \%$. Sedang $50 \%$ dan rendah $5 \%$. Hasil persentase dalam aspek materi siswa pada siklus I adalah tinggi $0 \%$, sedang $70 \%$ dan rendah $30 \%$, pada siklus II peningkatannya menjadi tinggi $15 \%$, sedang $85 \%$ dan rendah $0 \%$. Dari uraian di atas, dapat dilihat bahwa dari pengamatan terhadap siswa setiap siklusnya mengalami peningkatan. Dan pada akhirnya siklus dihentikan dikarenakan siswa telah memiliki prestasi belajar yang sangat baik. Sebanyak 20 siswa (100\%) telah mencapai KKM. Sehingga siklus diberhentikan pada siklus II dan media video scribe dianggap berhasil untuk meningkatkan prestasi hasil belajar siswa pada kelas V di SD Negeri 25 Sungai Kakap.

Berdasarkan data rekapitulasi dari penelitian yang dilakukan, menunjukkan terjadi peningkatan peningkatan prestasi hasil belajar siswa dari sebelum dilakukan tindakan (pra tindakan) bahwa siswa yang mencapai ketuntasan hanya $25 \%$ dari keseluruhan jumlah siswa. Pada siklus I setelah menerapkan Media Video scribe ketuntasan hasil belajar siswa meningkat menjadi $60 \%$ dan pada siklus II mencapai $100 \%$. Dari proses peningkatan prestasi belajar siswa tersebut dapat disimpulkan bahwa media merupakan alat bantu atau perantara penyampaian materi pembelajaran sangat penting digunakan, terutama media audio visual yang menarik seperti Media video scribe ini.

\section{SIMPULAN DAN SARAN Simpulan}

Berdasarkan hasil penelitan tindakan kelas yang telah dilakukan maka dapat disimpulkan bahwa dapat disimpulkan bahwa pemanfaatan media video scribe dapat meningkatkan hasil belajar PAI materi cita-citaku menjadi anak salih pada siswa kelas V SD Negeri 25 Sungai Kakap menunjukkan peningkatan pada setiap siklusnya, yaitu dari data dari pra tindakan yang telah didapat kemudian dilakukan treatmen dalam proses pembelajaran dengan media video scribe 
menunjukkan siklus I mengalami kenaikan ketuntasan siswa sebanyak $25 \%$, dan dari siklus I dilanjutkan siklus II mengalami kenaikan menjadi $60 \%$. Pada siklus II ini diberhentikan karena $100 \%$ siswa telah mencapai ketuntasan, sehingga penerapan media video scribe tersebut dapat dikatakan berhasil dalam meningkatkan hasil belajar PAI materi cita-citaku menjadi anak salih kelas V SD Negeri 25 Sungai Kakap.

\section{Saran}

Setelah melakukan penelitian ini, peneliti dapat menyampaikan beberapa saran sebagai berikut: (1) Bagi guru, dalam proses pembelajaran hendaknya menggunakan media pembelajaran agar siswa menjadi lebih aktif di kelas serta menunmbuhkan motivasi karena pembelajaran yang dilakukan kreatd dan berbeda dari situasi pembelajaran biasanya, sebagai pendidik dapat menggunakan media video scribe pada pembelajaran Pendidikan Agama Islam untuk meningkatkan hasil belajar siswa; (2) Bagi siswa,lebih menyadari untuk berpartisipasi aktif dalam kegiatan pembelajaran beriktnya serta lebih berani mengungkapkan pendapatnya dalam proses pembelajaran; (3) Bagi Sekolah ,hendaknya pihak sekolah memberikan motivasi kepada para pendidik agar memanfaatkan media pembelajaran sebagai alat bantu dalam menyampaikan materi pembelajaran yang mampu memudahkan peserta didik memahami materi pelajaran yang disajikan, pihak sekolah lebih meningkatkan sarana dan prasaran yang mendukung proses pembelajaran.

\section{DAFTAR PUSTAKA}

Amrullah, M. Amin. 2014. Panduan Menyusun Proposal Skripsi, Tesis \& Disertasi. Yogyakarta: Smart Pustaka

Arikunto, Suharsimi. 2008. Prosedur Penelitian Suatu Pendekatan Praktik.Jakarta: PT Bina Aksara.
Arief, Sadiman. 2010. Media Pendidikan. Jakarta: PT.RajaGrafindo.

Daryono, 2018. Penelitian Tindakan Sekolah dan Penelitian Tindakan Sekolah.Yogjakarta:Gava Media

Djamarah, Syaiful Bahri dan Aswan Zain. 2010. Strategi Belajar Mengajar.Jakarta: Rineka Cipta.

Daradjat, Zakiah. 2011. Ilmu Pendidikan Islam. Jakarta: Bumi Aksara Hamalik, Oemar. 1995. Kurikulum dan Pembelajaran. Jakarta. Bumi Aksara.

H.E Mulyasa. 2011. Praktik Penelitian Tindakan Kelas. Bandung: Remaja Rosdakarya

Khodijah,Nyayu. 2014. Psikologi Pendidikan. Jakarta: Raja Grafindo Persada.

Mujiono \& Dimyati. 1999. Proses Belajar Mengajar. Jakarta: Bumi Aksara Purwanto, Ngalim. 1996. Psikologi Pendidikan. Bandung : PT Remaja Rosdakarya

Roestiyah. 1986, Masalah-masalah Ilmu Keguruan. Jakarta: Bina Aksara

Rusmono. 2012. Strategi Pembelajaran Dengan Problem Based Learning Itu Penting. Bogor: Gahalia Indonesia

Sudjana, Nana. 2006. Dasar-dasar Proses Belajar Mengajar. Jakarta: Bumi Aksara Syah, Muhibbin. 1999. Psikologi-Cet.1. Jakarta : PT Logos Wacana Ilmu.

Sumantri.2011. Perkembangan Peserta Didik.Tangerang Selatan: Penerbit Universitas Terbuka

Trianto. 2013. Mendesain Model Pembelajaran Inovatif Progresif. Jakarta: Kencana Prenada Media Group

Wijaya Kusuma, 2009. Mengenal Penelitian Tindakan Kelas. Jakarta. PT Indeks Yamin, Martinis. 2005. Strategi Pembelajaran Berbasis Kompetensi. Ciputat. Gaung Persada Press. 